\title{
Análise dos aspectos éticos da pesquisa em seres humanos contidos nas instruções aos autores de 38 revistas de ortopedia e traumatologia*
}

\author{
Analysis of the research with human beings ethical aspects included in the guidelines \\ of thirty-eight orthopedics and traumatology journals.
}

Trajano Sardenberg ${ }^{1}$, Sergio S. Müller ${ }^{2}$, Hamilton R. Pereira², Reinaldo A. de Oliveira², Willam S. Hossine ${ }^{3}$

\section{RESUMO}

O objetivo do estudo foi analisar as normas relativas à ética da pesquisa em seres humanos contidas nas Instruções aos Autores de revistas de ortopedia e traumatologia. Trinta e oito revistas foram estudadas observando-se que $52,6 \%$ não fazem referência a aspectos éticos, 28,9\% exigem aprovação por Comitê de Ética da Instituição, 15,7\% seguem orientação dos Requisitos Uniformes para Manuscritos Submetidos a Revistas Biomédicas e 2,6\% solicitam o consentimento do paciente. Aspectos relacionados à privacidade dos pacientes são citados em $36,8 \%$ das revistas estudadas. Os resultados indicam que a maioria das revistas de ortopedia e traumatologia apresenta pouca preocupação com os aspectos éticos de pesquisa em seres humanos nas Instruções aos Autores.

Descritores: Ética; pesquisa; publicação

\section{INTRODUÇÃO}

O documento internacional de maior importância no meio científico médico e biomédico que orienta a pesquisa em seres humanos é a Declaração de Helsinque da Associação Médica Mundial (aprovada em 1964 e revista em 1996), a qual explicita que "relatos de experimentação fora dos princípios desta Declaração não devem ser aceitos para a publicação ${ }^{(6)}$. O ConseIho Nacional de Saúde do Ministério da Saúde aprovou em 1996 a Resolução 196/96 que regulamenta e orienta a pesquisa em seres humanos no Brasil( ${ }^{(4)}$. O Código de Ética Médica Brasileiro de 1988 apresenta referências à pesquisa médica e à publicação de trabalhos científicos ${ }^{(3)}$.

Revistas importantes da área de medicina e biomedicina fazem referências à ética nas suas Instruções aos Autores ${ }^{(1,5)}$.

\section{SUMMARY}

The aim of this study was to analyze the norms about ethics in research with human beings included in the guidelines of orthopedics and traumatology scientific journals. Thirty-eight journals were analyzed: 52,6\% do not mention ethical aspects, 28,9\% submit to approval by the Institution's Ethical Committee, 15,7\% follow the orientation of the Uniform Requirements for manuscripts submitted to biomedical journals, and 2,6\% ask the patients ' consent; aspects related to the patients ' privacy were found in $36,8 \%$ of the studied journals. The results indicate that most orthopedics and traumatology journals show little concern with the human beings research ethical aspects in their guidelines.

Key words: Ethics; research; publication

\section{INTRODUCTION}

The most important international document which orientates research with human beings is the Declaration of Helsinki of the World Medical Association (approved in 1964 and revised in 1996). It states that "reports of experiences out of the principles of this Declaration must not be accepted for publication"(6). In 1996, the Ministry of Health National Council approved the Resolution 196/96 which regulates and orientates research with human beings in Bra-

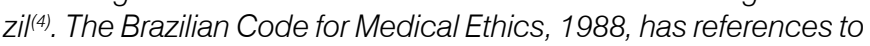
medical research and to the publication of scientific papers ${ }^{(3)}$.

Important journals of medicine and biomedicine make references to ethics in their guidelines ${ }^{(1,5)}$.

The aim of this study was to study the research with human beings ethics found in the guidelines of orthopedics and traumatology journals.
* Trabalho realizado no Departamento de Cirurgia e Ortopedia da Faculdade de Medicina de Botucatu da Universidade Estadual Paulista Júlio de Mesquita Filho (FMB - UNESP)

1- Professor Assistente

2- Professor Assistente Doutor

3- Professor Emérito

Endereço para Correspondência: Trajano Sardenberg - Departamento de Cirurgia e Ortopedia - Faculdade de Medicina de Botucatu - UNESP - Botucatu SP Cep: 18.618.970 - email: tsarden@fmb.unesp.br
*Work performed at the Orthopedics and Surgery Department from Faculdade de Medicina de Botucatu, Universidade Paulista Júlio de Mesquita Filho (FMB - UNESP)

1- Assistant Professor

2- Assistant Professor Doctor

3- Emeritus Professor

Address: Trajano Sardenberg - Departamento de Cirurgia e Ortopedia

Faculdade de Medicina de Botucatu - UNESP - Botucatu - SP

CEP: 18618-970 - Email: tsarden@fmb.unesp.br 
O objetivo do presente estudo foi estudar a ética da pesquisa em seres humanos, contida nas Instruções aos Autores de revistas de ortopedia e traumatologia.

\section{MATERIAIS E MÉTODOS}

As Instruções aos Autores de 38 revistas de ortopedia e traumatologia foram analisadas segundo metodologia desenvolvida por Amdur e Biddle ${ }^{(1)}$ adaptada por Sardenberg et al(5).

As revistas foram classificadas segundo a ética das Instruções aos Autores em 4 grupos:

1- Comitê ou Comissão de Ética:- revistas que fazem referência à necessidade de aprovação do estudo por Comitê ou Comissão de Ética, independente de outras recomendações éticas;

2- Requisitos Uniformes:- revistas que fazem referência direta aos "Requisitos Uniformes para Originais Submetidos a Revistas Biomédicas" do Comitê Internacional de Editores de Revistas Médicas ${ }^{(2)}$;

3- Consentimento do paciente:- revistas que referem-se fundamentalmente ao consentimento do paciente;

4- Sem orientações éticas:- revistas que não apresentam referências a aspectos éticos na pesquisa em seres humanos.

As revistas que fazem referência à Declaração de Helsinque ${ }^{(6)}$, independente de outras exigências éticas, foram identificadas.

Os aspectos relativos à privacidade, como a não utilização de imagens e de nomes ou iniciais de nomes que possam identificar os pacientes, foram analisados em relação à sua presença ou ausência.

\section{RESULTADOS}

Os resultados (Tabelas 1 a 6).

\section{DISCUSSÃO}

Apesar dos critérios flexíveis utilizados no presente estudo, isto é, qualquer referência direta ou indireta à ética da pesquisa em seres humanos contida nas Instruções aos Autores foi considerada e analisada, o número de revistas que fazem referência à ética foi baixo (47,3\%). Em estudo de revistas de medicina e biomedicina de língua inglesa observaram $^{(1)}$ que $76 \%$ fazem referência à ética nas Instruções aos Autores. No entanto, em estudo com 139 revistas científicas brasileiras da área de saúde, obser-

\section{MATERIAL AND METHODS}

The guidelines from 38 orthopedics and traumatology journals were analyzed according to the methodology developed by Amdur and Biddle ${ }^{(1)}$ and adapted by Sardenberg et $\mathrm{al}^{(5)}$.

The journals were classified according to the ethics contained in the guidelines in four groups:

1 - Ethics Committee or Commission: journals which make reference to the necessity of approval by the Ethics Committee or Commission, independently of other ethical recommendations;

2 - Uniform Requirements - journals which make direct reference to the "Uniform Requirements for Manuscripts Submitted to Biomedical Journals" of the International Committee of Medical Journals Editors ${ }^{(2)}$;

3 - Consent of the Pacient - journals which mention fundamentally the patient's consent;

4 - No Guidelines Concerning Ethics: journals which do not mention the ethical aspects of the research with human beings.

The journals which mention the Helsinki Declaration ${ }^{(6)}$, independently of other ethical demands were identified.

Aspects related to privacy as the non-utilization of images and names or initials which can identify the patients were analyzed as concerns their presence or absence.

\section{RESULTS}

The results are presented in (Tables 1 to 6).

\section{DISCUSSION}

In spite of the flexible criteria used in this study, that is, any direct or indirect reference to ethics in research with human beings contained in the guidelines was considered and analyzed, the number of journals which mention ethics was low (47.3\%). The study ${ }^{(1)}$ of medical and biomedical journals in the English language has shown that $76 \%$ of them mentioned ethics in their guidelines. However, studying 139 Brazilian scientific journals related to health, the authors ${ }^{(5)}$ observed that only $20.8 \%$ made ethical references in their guidelines.

\begin{tabular}{|lcc|}
\hline Com referências à ética & 18 & $(47,3 \%)$ \\
\hline Sem referências à ética & 20 & $(52,6 \%)$ \\
\hline Fonte: FMB - UNESP & $\mathrm{n}=38$ & $(100 \%)$ \\
\hline
\end{tabular}

Tabela 1 - Freqüência absoluta e relativa das referências à ética da pesquisa em seres humanos contidas nas Instruções aos Autores de 38 revistas de ortopedia e traumatologia.

Table 1 - Absolute and relative frequency of ethical standards in human being research included in the guidelines of 38 orthopaedics and traumatology journals.
In this sample, the journals which made references to ethics showed preference for the "Ethics Commission or Committee" approval (28.9\%) followed by the orientations of the Uniform Requirements $(15.7 \%)^{(1,5)}$.

The Helsinki Declaration states that research protocols for human beings must be analyzed by a committee independent from the author and that reports of experiences in disagreement with these principles must not be accepted for publication. The Declaration of Helsinki also demands that the pati- 
varam $^{(5)}$ que somente $20,8 \%$ apresentam referências éticas nas Instruções aos Autores.

As revistas que fazem referência à ética, na presente amostra, apresentaram preferência pela aprovação do "Comitê ou Comissão de Ética" $(28,9 \%)$ seguida das orientações dos Requisitos Uniformes (15,7\%), resultados semelhante aos observados ${ }^{(1,5)}$.

A Declaração de Helsinque explicita que os protocolos de pesquisa em seres humanos devem ser analisados por comitê independente do autor e que relatos de experimentação em desacordo com estes princípios não devem ser aceitos para publicação. A Declaração de Helsinque exige ainda, o consentimento da pessoa em participar da pesquisa.

Os "Requisitos Uniformes" contém orientações éticas mais frágeis, pois afirmam somente que os autores devem informar "se os procedimentos foram realizados de acordo com os padrões éticos do comitê responsável por experimentação humana (Institucional ou regional) e com a Declaração de Helsinque de 1975 , tal como a revista em $1997^{(2)}$.

A preservação da privacidade dos pacientes que participam de pesquisa científica está baseada nos princípios da ética médica relacionados ao segredo médico, presente no Juramento de Hipócrates e contemplados na Declaração de Helsinque e nos Requisitos Uniformes. $\mathrm{Na}$ presente amostra, somente $36,8 \%$ das revistas apresentam referências à privacidade, geralmente relacionadas à identifica-

\begin{tabular}{llll}
\hline Comitê ou Comissão de Ética / Institucional & 11 & $(28,9 \%)$ \\
\hline Requisitos Uniformes & 6 & $(15,7 \%)$ \\
\hline Consentimento do paciente & 1 & $(2,6 \%)$ \\
\hline Sem referências à ética & 20 & $(52,6 \%)$ \\
\hline Fonte: FMB - UNESP & $n=38$ & $(100 \%)$ \\
\hline
\end{tabular}

Tabela 2 - Freqüência absoluta e relativa dos tipos de referências à ética da pesquisa em seres humanos contidas nas Instruções aos Autores de 38 revistas de ortopedia e traumatologia.

Table 2 - Absolute and relative frequency about the kind of ethical standards in human being research included in the guidelines of 38 orthopaedics and traumatology journals.

\begin{tabular}{lll}
\hline Fazem referência á privacidade & 14 & $(36,8 \%)$ \\
\hline Não fazem referência á privacidade & 24 & $(63,1 \%)$ \\
\hline Fonte: FMB - UNESP & $n=38$ & $(100 \%)$ \\
\hline
\end{tabular}

Tabela 3 - Freqüência absoluta e relativa das referências à ética da pesquisa em seres humanos relacionadas à privacidade dos pacientes, contidas nas Instruções aos Autores de 38 revistas de ortopedia e traumatologia.

Table 3 - Absolute and relative frequency of ethical standards in human being research related to patient's confidentiality included in the guidelines of 38 orthopaedics and traumatology journals.

\begin{tabular}{l}
\hline Chirurgie de la main \\
\hline Journal of Bone and Mineral Research \\
\hline Journal of Bone Joint Surgery (American Volume) \\
Journal of Hand Surgery (American Volume) \\
\hline Journal of Hand Surgery (British and European Volume) \\
\hline Journal of Pediatric Orthopaedics \\
\hline Orthopaedics \\
\hline Osteoporosis International \\
Fonte: FMB - UNESP
\end{tabular}

Tabela 4 - Revistas de Ortopedia e traumatologia que fazem referência à Declaração de Helsinque, em conjunto com outras orientações nas Instruções aos Autores.

Table 4 - Orthopaedic and traumatology journals that quoted Declaration of Helsinki plus other orientations at the guidelines. ents give their consent to participate in the study.

The "Uniform Requirements" contain a more fragile ethical orientation, since they state only that the authors should inform "whether the procedures were performed in accordance with the ethical standards of the committee responsible for the human experimentation (institutional or regional) and with the 1975 Declaration of Helsinki, as well as the revised one in 1997(2).

Preservation of the patients privacy when participating in scientific research is based in the medical ethics principles related to medical confidentiality, present in the Hyppocratic Oath and contemplated in the Declaration of Helsinkiand in the Uniform Requirements. In this sample, only $36.8 \%$ of the journals make references to privacy, in general related to the identification of patients in photographs or by the use of names or initials.

\section{CONCLUSIONS}

The orthopedics and traumatology journals are little concerned with the ethical aspects of the guidelines.

Ethics in research with human beings and the publication of scientific papers are polemical themes; however, the world tendency is to demand high ethical standards in the realization of scientific studies to be published in the medical literature.

\section{ACKNOWLEDGEMENTS}

The authors thank Ms. Enilze de Souza Nogueira Volpato and Ms. Thereza de Fátima Gonzales Torres for obtaining material for this study. 


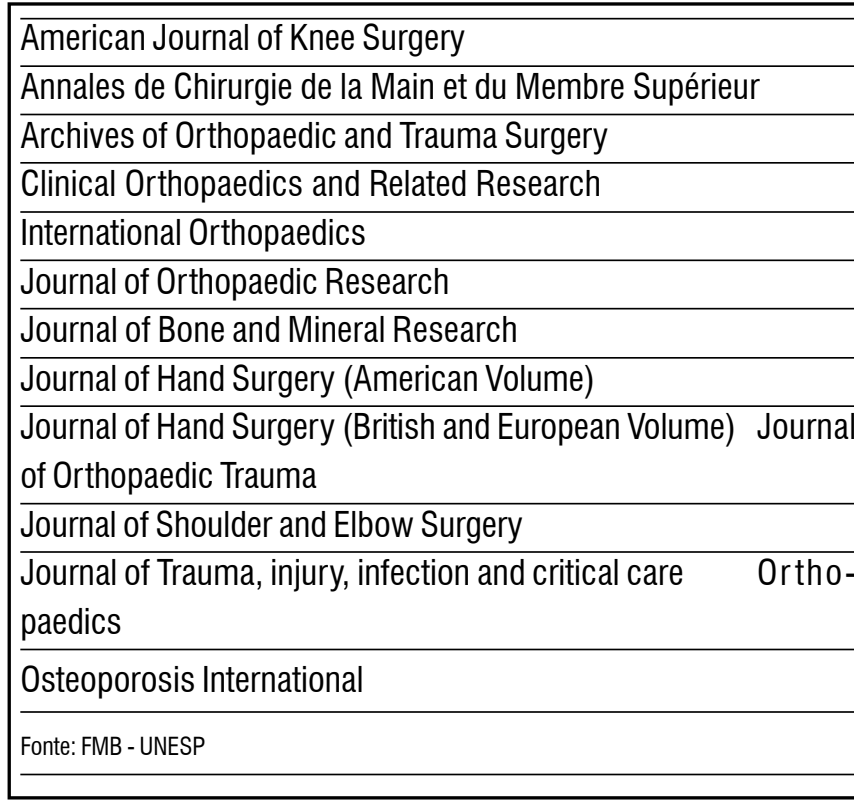

Tabela 5 - Revistas de Ortopedia e Traumatologia que fazem referência à privacidade dos pacientes nas suas Instruções aos Autores.

Table 5 - Orthopaedic and traumatology journals that quoted patient's confidentiality at the guidelines.

ção de pacientes em fotografias ou pelo uso de nomes ou iniciais de nomes.

\section{CONCLUSÕES}

As revistas de ortopedia e traumatologia tem pouca preocupação com os aspectos éticos nas Instruções aos Autores.

A ética da pesquisa em seres humanos e a publicação de artigos científicos são tema polêmico, no entanto, a tendência mundial encontra-se na exigência de padrões éticos elevados na execução de estudos científicos submetidos à publicação na literatura médica.

\section{AGRADECIMENTO}

Os autores agradecem as Sras. Enilze de Souza Nogueira Volpato e Thereza de Fátima Gonzales Torres pela obtenção do material desse estudo.

\section{REFERÊNCIAS BIBLIOGRÁFICAS}

1. Amdur, R.J., Biddle, C.: Institucional review board approval and publication of human research results. JAMA 277:904-914, 1997.

2. Comitê internacional de editores de revistas médicas: Requisitos uniformes para originais submetidos a revistas biomédicas. J Pediatr 73:213-224, 1997

3. Conselho Federal de Medicina: Código de ética médica, 1988.

4. Conselho Nacional de Saúde - Ministério da Saúde: Diretrizes e

\section{Comitê ou Comissão de Ética/Institucional}

Chirurgie de la Main

Journal of Bone and Joint Surgery (American Volume)

Journal of Bone and Mineral Research

Journal of Hand Surgery (American Volume)

Journal of Hand Surgery (British and European Volume)

Journal of Orthopaedic Research

Journal of Pediatric Orthopaedics

Journal of Trauma, injury, infection and critical care

Orthopaedics

Osteoporosis International

Revista Mexicana de Ortopedia Pediátrica

\section{Requisitos Uniformes}

Acta Orthopaedic Scandinavica

International Orthopaedics

Journal of Orthopaedic Trauma

Journal of Shoulder and Elbow Surgery

Revista de la Associacion Argentina de Ortopedia y Traumatologia

Revista Mexicana de Ortopedia

\section{Consentimento do paciente}

\section{Spine}

\section{Sem referências Éticas}

Acta Orthopaedic Belgica

Acta Ortopédica Brasileira

American Journal of Knee Surgery

Annales de Chirurgie de la Main et du Membre Supérieur

Archives of Orthopaedic and Trauma Surgery

Arthroscopy - Journal of Arthroscopic \& Related Surgery

Clinical Orthopaedics and Related Research

European Spine Journal

Journal of Arthrosplasty

Journal of Bone and Joint Surgery (British)

Journal of Foot \& Ankle Surgery

Journal of Pediatric Orthopaedics - Parte B

Journal of Reconstructive Microsurgery

Orthopaedic Surgery

Osteoarthrits and Cartilage

Revue de Chirurgie Orthopedique

Revista Brasileira de Ortopedia

Revista Colombiana de Ortopedia y Traumatologia

Revista Cubana de Ortopedia

Revista de la Sociedad Andaluza de Traumatologia y Ortopedia Fonte: FMB - UNESP

Tabela 6 - 38 revistas de ortopedia e traumatologia classificadas de acordo com as referências aos aspectos éticos da pesquisa em seres humanos contidos nas Instruções aos Autores.

Table 6 - Classification of 38 orthopaedic and traumatology journals related to ethical standards in human being research included at the guidelines.

normas regulamentadoras da pesquisa em seres humanos - ResoIução 196,1996.

5. Sardenberg, T., Müller, S.S., Pereira, H.R., Oliveira, R.A., Hossne, W.S.: Análise dos aspectos éticos da pesquisa em seres humanos contidos nas Instruções aos Autores de 139 revistas científicas brasileiras. Rev Ass Med Brasil 45:295-302, 1999.

6. World Medical Association: Declaration of Helsinki. JAMA 277:925926, 1997. 